\title{
HALLUCINATION AND RISK FACTORS IN PATIENTS WITH PARKINSON'S DISEASE
}

\author{
Parkinson Hastalarında Halusinasyon ve Risk Faktörleri
}

\author{
Bahar SAY ${ }^{1}$, Yasemin ÜNAL ${ }^{2}$, Tuğba TUNÇ${ }^{3}$, Gülnihal KUTLU $^{4}$, Ufuk ERGÜN ${ }^{5}$
}

\author{
${ }^{1,5}$ Kirikkale University Faculty of Medicine, Department of Neurology, KIRIKKALE, TÜRKIYE \\ ${ }^{2,4}$ Mugla Sitki Kocman University Faculty of Medicine, Department of Neurology, MUĞLA, TÜRKIYE \\ ${ }^{3}$ Gazi University Faculty of Medicine, Department of Neurology, ANKARA, TÜRKIYYE
}

\begin{abstract}
Objective: Hallucination is one of the non-motor symptoms in Parkinson disease (PD). Several factors may affect the presence of hallucination. In the present study, we aimed to compare PD patients presenting with and without hallucinations, to determine risk factors, and to find out common hallucination types.
\end{abstract}

Material and Methods: Idiopathic Parkinson patients regarding to UK Parkinson Disease Society Brain Bank with and without hallucinations were compared. The patients with psychotic symptoms due to metabolic, infectious, and structural causes were excluded. Disease severity was evaluated by Unified Parkinson Disease Rating Scale and Hoehn and Yahr staging. Cognitive status was assessed by Minimental State Examination test. Depression was diagnosed on the basis of DSM-V Tr. Description of hallucination, treatment, co-morbidity, sleep disturbances, REM sleep behavioral disorder, age, gender, scores of test and scale, stage of disease were recorded.

Results: A total of 91 (59 female, 32 male) patients with idiopathic PD were enrolled. The group with hallucinations (Group 1) had $40(43.9 \%)$ patients and the one without hallucinations (Group 2) had 51 (54.9\%) patients. Total score of Unified Parkinson Disease Rating Scale was significantly higher in Group 1 than Group $2(37.83 \pm 16.65 ; 30.18 \pm 14.83$; $\mathrm{p}=0.028)$. Sleep disturbances were high in Group $1(\mathrm{n}=24,60 \%)$ when compared to Group $2(\mathrm{n}=14,27.4 \%)(\mathrm{p}=0.007)$. The mean duration of hallucinations was $24.87 \pm 56.47$ months in Group 1 . Twenty-one patients (23.9\%) had visual hallucinations; 15 (16.5\%) patients had illusions (minor hallucinations); and four (4.4\%) patients had auditory hallucinations.

Conclusion: Disease severity in Parkinson's disease may be a factor in the presence of hallucinations. Hallucinations may also occur with sleep disorders. Minor hallucinations are frequently observed in early stages, with visual hallucinations being the most common hallucinations that may occur in every disease stage.

Keywords: Minor hallucination, visual hallucination, disease severity, sleep

\section{ÖZ}

Amaç: Halusinasyon Parkinson hastalığındaki non-motor semptomlardan biridir. Halusinasyon varlığında birçok risk faktörü rol oynayabilir. Bu çalışmada halusinasyonu olan ve olmayan Parkinson hastalarının karşılaştırılması, risk faktörlerinin belirlenmesi, sık görülen halusinasyon tiplerinin bulunması amaçland.

Gereç ve Yöntemler: İngiltere Beyin Bankası kriterlerine gore idiopatik Parkinson hastalığı tanısı olan hastalarda halusinasyonu olan ve olmayanlar karşılaştırıldı. Metabolik, enfeksiyöz ve yapısal nedenlere bağlı psikotik semptomu olan hastalar çalışmaya dahil edilmedi. Hastalık şiddeti Birleşik Parkinson Hastalığı Değerlendirme Ölçeği ve Hoehn ve Yahr evrelemesine göre belirlendi. Kognitif durum Minimental Durum Değerlendirme testi ile değerlendirildi. Depressif duygu durum tanis1 DSM-5 ile konuldu. Mevcut ise halusinasyon tanımlaması, tedavi, komorbidite, uyku bozuklukları, REM uyku davranış bozukluğu, yaş, cinsiyet, ölçek ve test skorları ile hastalık evresi kayıt edildi.

Bulgular: Çalışmaya toplam 91 (59 kadın, 32 erkek) idiopatik Parkinson hastası alındı. Halusinasyonu olan grup (Grup 1) da 40 (\%43.9), halusinasyonu olmayan grupta (Grup 2) 52 (\%54.9) hasta vardı. Birleşik Parkinson Hastalığ Değerlendirme Ölçeği toplam skoru Grup 1 de Grup 2 ye göre anlamlı oranda yüksekti $(37.83 \pm 16.65 ; 30.18 \pm 14.83$; $\mathrm{p}=0.028)$. Uyku bozukluklar1 Grup $2 \quad(n=14, \% 27.4)$ ile karşılaştırıldığında Grup 1'de $(\mathrm{n}=24, \% 60)$ anlamlı oranda yüksekti ( $\mathrm{p}=0.007)$. Halusinasyon süresi Grup 1'de ortalama

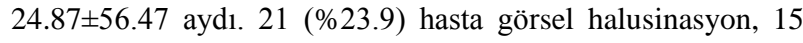
(\%16.5) hasta illuzyon (minör halusinasyon) ve dört (\%4.4) hasta işitsel halusinasyona sahipti.

Sonuç: Parkinson hastalığında hastalık şiddeti halusinasyon varlığında etken olabilir. Halusinasyonlar uyku bozuklukları ile birlikte görülebilir. Minör halusinasyonlar sıklıkla erken evrede izlenirken, en s1k görülen görsel halusinasyon her evrede izlenebilir.

Anahtar Kelimeler: Minör halusinasyon, görsel halusinasyon, hastalık şiddeti, uyku

\section{Dr. Bahar SAY}

Correspondence / Yazışma Adresi:

Yenişehir, Ankara Yolu 7.Km. Kırıkkale Üniversitesi Kampüsü, 71450, Yahşihan, KIRIKKALE, TÜRKIYYE

Phone / Tel: +900318 4444071

Received / Geliş Tarihi: 13.09.2019

${ }^{1} 0000-0003-2595-3804{ }^{2} 0000-0002-6110-9558$

E-mail / E-posta: drbaharsay@gmail.com

Accepted / Kabul Tarihi: 20.12.2019

${ }^{3} 0000-0001-6510-7931{ }^{4} 0000-0002-9325-4151$ 


\section{INTRODUCTION}

Parkinson disease (PD) is the second most common movement disorder after tremor. Its prevalence increases with aging and it affects more than $1 \%$ of people older than 60 years. Its cardinal motor signs include bradykinesia/akinesia, tremor, rigidity, and postural instability. The diagnosis of the disease is made if one of the other signs is present in addition to bradykinesia $(1,2)$. The non-motor symptoms including neuropsychiatric, gastrointestinal, cardiovascular, urological, sleep and sexual function disorders may also accompany the motor symptoms. Psychosis is one of the common non-motor symptoms.

Hallucination is an unreal perception without outside stimulus. It is simple at early PD but becomes complex at advanced stage (3). Visual hallucinations are the most common type (4). Defining hallucinations is an important task for determining and correcting risk factors and improving patients' and their relatives' quality of life. In the present study it was aimed to compare PD patients with and without hallucinations, to determine risk factors, and to find out common hallucination types.

\section{MATERIALS AND METHODS}

Patients with idiopathic PD were allocated from two tertiary centers. All patients were evaluated clinically by two neurologists. Parkinson's patients with hallucination (Group 1) were compared with Parkinson's patients without hallucination (Group 2). This study was approved by the university's ethics committee (Date: 24.07.2019; decision number:2019/11-2019.06.21). All patients or their relatives were provided written informed consent.

\section{Selection of Patients}

This study included patients with resting tremor, rigidity, or postural instability in addition to bradykinesia on the basis of UK Parkinson Disease Society Brain Bank (UKPDSBB) criteria and known levodopa response. Patients with conditions potentially causing secondary parkinsonism, such as hydrocephalus, brain tumor, recurrent head trauma, and long-term neuroleptic use prior to PD onset were excluded, as were those with sudden-onset disease symptoms or with a gradual progression, those without levodopa response, and those having Parkinson plus (2). Patients with psychotic symptoms due to metabolic, infectious, and structural causes were also excluded.

\section{Clinical Assessment of Patients}

Patients were assessed on the basis of UPDRS and Hoehn and Yahr (H\&Y) staging for disease severity. Cognitive status was evaluated by Minimental Status Examination (MMSE). Depression was diagnosed on the basis of DSM-V Tr scales. Diagnosis was made by the presence of at least five of the disturbances including weight and sleep problems, psychomotor agitation or retardation, fatigue or energy loss, feeling of worthlessness, reduced concentration, and thought of death in addition to at least one of depressed mood for at least two weeks, loss of interest in favorite activities or things, or inability to enjoy (5). Sleep disorders were questioned as daytime sleepiness, night sleep disturbances.

Presence of hallucinations, and if present, their detailed description, treatment, patients' co-morbidities, REM sleep behavioral disorder (RBD), sleep disturbances, scores of test and, if present, depressive mood were recorded. Information about patients who were unable to respond was obtained from a relative or caregiver. All examinations and data recording were done by neurologists.

\section{Unified Parkinson Disease Rating Scale (UPDRS)}

This scale assesses many aspects of PD and provides a clinical ratio for disease severity. It consists of four sections, namely mental section, motor examination, daily life activities (DLA), and treatment complications. The sections are scored between 0 (no 
symptom or sign) and 4 (severe symptom or sign possible) (6).

\section{Hoehn and Yahr (H\&Y) Staging}

Staging of Parkinson disease is done with the H\&Y scale. Accordingly, the disease is defined in 5 stages (7).

\section{Minimental Status Examination (MMSE)}

Used for evaluation of cognitive status, this test assesses 5 cognitive domains, namely orientation (10 points), registration ( 3 points), attention and calculation (5 points), recall (3 points), and language ( 9 points). Over a total of 30 points, $27-20$ points indicate normal cognition; 24-26 points indicate mild cognitive impairment; and below 24 points indicate dementia $(8,9)$.

\section{Statistical Analysis}

The study data were analyzed using SPSS 21 (SPSS Inc, Chicago, III, USA) software package. The results were expressed as mean \pm standard deviation for normally distributed variables and median (minimummaximum) for non-normally distributed ones. $\mathrm{P}<0.05$ was considered statistically significant. Inter-group comparisons were performed with Chi-Square test or Fisher's exact test for categoric variables, independent samples $\mathrm{t}$ test for normally distributed quantitative variables, and Mann Whitney-U test for non-normally distributed quantitative variables. More than two groups were compared with Kruskal-Wallis test. Correlations between study variables were tested with Pearson correlation test.

\section{RESULTS}

A total of 91 (59 female, 32 male) patients with PD were enrolled in this study. There were 40 (43.9\%) patients (27 male, 13 female) in Group 1 and 51 (54.9\%) patients (32 male and 19 female) in Group 2. The two groups did not differ significantly with respect to age and $\operatorname{sex}(\mathrm{p}=0.139 ; 0.637$ respectively).
Demographic and clinical characteristics of the study group are presented in Table 1. The total UPDRS score was significantly higher in Group 1 than Group 2 $(37.83 \pm 16.65 ; \quad 30.18 \pm 14.83 ; \quad \mathrm{p}=0.028)$. Sleep disturbances were high in Group $1(n=24,60 \%)$ compared to Group $2(\mathrm{n}=14,27.4 \%)(\mathrm{p}=0.007)$. In Group 1, $17(41.4 \%)$ patients had sleep problems at night and 7 (17\%) patients had daytime sleepiness.

The groups did not differ significantly with respect to other characteristics. According to $\mathrm{H} \& \mathrm{Y}$ staging, 8 (20\%) patients in Group 1 had stage 1 disease; 23 (57.5\%) patients had stage 2 disease; 7 (17.5\%) patients had stage 3 disease; and 2 patients had stage 4 disease. Nineteen (37.3\%) patients in Group 2 had stage 1 disease; $27(52.9 \%)$ patients had stage 2 disease; and 5 (9.8\%) patients had stage 3 disease. The groups had no significant differences with respect to the H\&Y stage $(\mathrm{p}=0.110)$.

The comparison with regard to the UPDRS subgroup scores revealed that mental subscore and DLA scores were significantly higher in group 1 compared to Group 2 (4.38 $\pm 1.82 ; 2.55 \pm 1.99 \mathrm{p}<0.001 ; 13.05 \pm 6.86$, $9.78 \pm 6.20 ; \mathrm{p}=0.001)$ (Table 2).

A treatment-based analysis showed a significant difference between the two groups with regard to COMT inhibitor (with levodopa) and antipsychotic use ( $\mathrm{p}=0.038 ; 0.040$ respectively) (Table 3 ). The mean duration of hallucinations was $24.87 \pm 56.47$ months. Twenty-one (23.9\%) patients had visual hallucinations; $15(16.5 \%)$ patients had illusions (minor hallucinations); four (4.4\%) patients had auditory hallucinations. The distribution of hallucinations was assessed by H\&Y staging (Table 4). Among patients with visual hallucinations, three patients saw hallucinations in the form of a close relative; one patient saw a distant relative; five patients saw an unknown person; five patients saw animals; four patients saw animals and humans; and three patients saw unidentified objects. Four patients with auditory hallucinations heard human voice. 
Table 1: Demographic and disease characteristics of Group 1 and Group 2

\begin{tabular}{|c|c|c|c|c|}
\hline Data & Total (n:91) & Group 1 (n:40) & Group 2 (n:51) & $\mathbf{p}$ \\
\hline Age, mean \pm SD & $71.08 \pm 8.74$ & $69.55 \pm 8.74$ & $72.27 \pm 8.64$ & 0.139 \\
\hline Gender, n (\%) & & & & 0.637 \\
\hline Female & $59(64.8)$ & $27(67.5)$ & $32(62.7)$ & \\
\hline Male & $32(35.2)$ & $13(32.5)$ & $19(37.3)$ & \\
\hline UPDRS total score & $33.54 \pm 16.03$ & $37.83 \pm 16.65$ & $30.18 \pm 14.83$ & $0.028 *$ \\
\hline MMSE score, mean \pm SD & $26.10 \pm 3.39$ & $26.45 \pm 3.07$ & $25.82 \pm 3.62$ & 0.413 \\
\hline Depression, n (\%) & $23(25.3)$ & $11(27.5)$ & $12(23.5)$ & 0.665 \\
\hline $\mathrm{RBD}, \mathrm{n}(\%)$ & $16(17.6)$ & $7(17.5)$ & $9(17.6)$ & 0.985 \\
\hline Sleep disturbances, n (\%) & $38(41.7)$ & $24(60)$ & $14(27.4)$ & $0.007 *$ \\
\hline \multicolumn{5}{|l|}{ Comorbidity, n (\%) } \\
\hline HT & $34(37.4)$ & $17(42.5)$ & $17(33.3)$ & 0.370 \\
\hline $\mathrm{DM}$ & $11(12.1)$ & $7(17.5)$ & $4(7.8)$ & 0.161 \\
\hline CVD & $13(13.9)$ & $5(12.1)$ & $8(15.3)$ & 0.279 \\
\hline COPD & $6(6.6)$ & $1(2.5)$ & $5(9.8)$ & 0.666 \\
\hline Malignancy & $3(3.3)$ & $1(2.5)$ & $2(3.9)$ & 0.224 \\
\hline Prostate & $3(3.3)$ & $1(2.5)$ & $2(3.9)$ & 1.000 \\
\hline Thyroid & $2(2.2)$ & - & $2(3.9)$ & 0.502 \\
\hline
\end{tabular}

*p<0.05 MMSE; Minimental Status Examination, UPDRS; Unified Parkinson's Disease Rating Scale, RBD; Rem Sleep Behaviour Disease, HT; Hypertension, DM; Diabetes Mellitus, CVD; Cardiovascular Disease, COPD; Chronic Obstructive Pulmonary Disease Group 1; Patients with hallucination, Group 2; Patients without hallucination

Table 2: Scores of UPDRS in Group 1 and Group 2

\begin{tabular}{llllc}
\hline UPDRS parts & Total $(\mathbf{n : 9 1})$ & Group 1 (n:40) & Group 2 (n:51) & p value \\
\hline UPDRS mental status & $3.35 \pm 2.11$ & $4.38 \pm 1.82$ & $2.55 \pm 1.99$ & $<0.001^{*}$ \\
UPPDRS motor & $17.84 \pm 9.25$ & $18.5 \pm 9.24$ & $17.31 \pm 9.31$ & 0.547 \\
UPDRS DLA & $11.22 \pm 6.67$ & $13.05 \pm 6.86$ & $9.78 \pm 6.20$ & $0.001^{*}$ \\
UPDRS complication & $0.41 \pm 0.94$ & $0.63 \pm 1.25$ & $0.24 \pm 0.55$ & 0.052
\end{tabular}

${ }_{* \mathrm{p}}^{*}<0.05$ UPDRS; Unified Parkinson's Disease Rating Scale, DLA; Daily Life Activities

Group 1; Patients with hallucination, Group 2; Patients without hallucination

Table 3: Treatment modalities in Group 1 and Group 2

\begin{tabular}{lcccc}
\hline Treatment, n (\%) & Total (n:91) & Group 1 (n:40) & Group 2 (n:51) & p value \\
\hline Levodopa & $35(38.4)$ & $11(27.5)$ & $24(47.1)$ & 0.058 \\
DA & $55(60.4)$ & $25(62.5)$ & $30(58.8)$ & 0.722 \\
COMT inhibitor & $53(58.2)$ & $36(90)$ & $17(33.3)$ & $<0.001^{*}$ \\
(with levodopa) & & & \\
Rasagiline & $29(31.9)$ & $15(37.5)$ & $14(27.5)$ & 0.307 \\
Amantadine & $4(4.4)$ & $4(10)$ & - & 0.034 \\
Antidepressant & $12(13.2)$ & $4(10)$ & $8(15.7)$ & 0.426 \\
Antipsychotic & $11(12.1)$ & $8(20)$ & $3(5.9)$ & $0.040^{*}$ \\
\hline
\end{tabular}

*p<0.005 DA; Dopamine Agonist, COMT; Catechol O-Methyltransferase,

Group 1; Patients with hallucination, Group 2; Patients without hallucination 
Table 4: Hallucinations according to disease stage in Group 1

\begin{tabular}{ccccc}
\hline Hoehn and Yahr stage & \multicolumn{1}{c}{ Hallucination, $\mathbf{n}(\%)$} & Total \\
\hline & Visual & Audituar & $5(62.5)$ & 8 \\
2 & $3(37.5)$ & - & $8(34.8)$ & 23 \\
3 & $13(56.5)$ & $2(8.7)$ & $2(28.6)$ & 7 \\
4 & $3(42.9)$ & $2(28.6)$ & - & 2 \\
\hline
\end{tabular}

\section{DISCUSSION}

In the present study, hallucinations and their risk factors in idiopathic PD were examined, and visual hallucinations were found to be most common form of hallucination. Total UPDRS score showed significant difference between the groups with and without hallucination.

The UPDRS is a widely accepted scale for rating PD's severity and progression (10). A higher total UPDRS score in the hallucinating group indicates that disease involvement and disease severity are more advanced. In PD, the incidence of hallucinations and psychosis may increase with disease severity (11). Furthermore, an analysis of UPDRS subgroups showed that the hallucinating group had significantly higher mental subscale and daily life activity scores. Questioning hallucination in the mental subscore caused a high score. Both groups had mild cognitive impairment. Worsening of cognitive status is one of the well-known risk factors for hallucination in Parkinson's disease. However, dementia is expected in advanced stage patients (12). According to disease H\&Y stage, there was a very small number of advanced patients, and the study may be limited in this manner; however, unintelligible speech, hypophonia, or aphonia may have prevented clinicians from noticing hallucinations or the rate of physician visits may have been reduced.

In Parkinson disease the agents used for therapy, especially dopamine agonists, amantadine and monoaminoxidase $\mathrm{B}$ inhibitors induce hallucinations by causing progressive dysfunction in amygdala, limbic system, and cortical centers where visual inputs are processed (13-15). High-dose levodopa may cause visual hallucinations in PD (16). In this study, the rate of the use of COMT inhibitor (with levodopa) was higher in patients with hallucination. Use of this combination was thought to be higher in patients with hallucination because of the severity of the disease. Additionally, antipsychotic agent use due to a need for symptomatic treatment was also higher among patients with hallucinations than those without. Treatment modalities of hallucination and pshycosis in PD include non-pharmacologic strategies, dose reduction of offending agents, and the addition of nondopaminergic antipsychotics (17).

Visual hallucinations are the most common hallucination form in PD and occur with a prevalence of $22-38 \%$ (18). Patients commonly see a family member or an unknown person. Seeing animals is the second most common type. They do not commonly create problems in patients' daily lives. The present study also revealed that hallucinations were mostly in the form of a human (unknown person) or animal. In PD, visual hallucination occurs in eldery with sleep disturbance. Sleep disorders in patients are thought to cause bad dreams and subsequent hallucinations (16). In a study conducted in Asian society, visual hallucinations were observed in $22.5 \%$ of HY I and II in Parkinson's patients and were associated with vivid dreams and sleep disorders (19). In this study, where visual hallucinations were frequently observed, sleep disorders were higher in patients with hallucinations. Visual hallucinations were observed at each stage regarding to $\mathrm{H} \& \mathrm{Y}$ staging. Second most commonly, patients suffered minor hallucinations in present study. The latter are also described as a sense of as if there 
was something, seeing a silhouette, or illusions. They may be seen from the early stages of the disease (20). Presence of sense is the most common minor hallucination $(15,21,22)$. They have been previously reported that it is present even in the premotor stage. They are not related to depression, anxiety, apathy, and treatment and closely related to RBD (23). In the present study, minor hallucinations were also observed at an earlier stage (stage 1) regarding to $H \& Y$. The groups did not differ with regard to depression and RBD. Minor hallucinations have been reported to occur in a lower proportion of normal populations than PD (24). In the present study auditory hallucinations were observed in a small number of cases (4 cases). The patients heard human voices. Two patients had isolated auditory hallucinations while two others had combined visual and auditory hallucinations. In patients with isolated auditory hallucinations, the latter disappeared upon gradual cessation of DA.

In PD auditory hallucinations are rarer than visual hallucinations. They do not show paranoid properties. They show an association with visual hallucinations in $8-13 \%$ of cases, but isolated occurrence is rare $(23,24)$. In a study of 216 Parkinson's patients, the hallucination rate was 39\%. Minor hallucination was observed in $25 \%$ of these cases, visual hallucination was observed in $22 \%$ and auditory hallucination was observed in $9.7 \%$ (isolated in $2.3 \%$ ) (25).

Tactile, olfactory hallucinations seen in PD were not observed in this study. Gustatory hallucinations, on the other hand, are reported in case reports in the literature $(21,26)$.

In summary, hallucinations may be seen in every stage of PD. Disease severity is an important determinant for the occurrence of hallucinations. Minor hallucinations are frequently observed in early stages, with visual hallucinations being the most common hallucinations that may occur in every disease stage.

Conflict of Interest: None

\section{REFERENCES}

1. Tysnes OB, Storstein A. Epidemiology of Parkinson's disease. J Neural Transm (Vienna). 2017;124(8):901-5.

2. Hughes AJ, Daniel SE, Kilford L, Lees AJ. Accuracy of clinical diagnosis of idiopathic Parkinson's disease: a clinico-pathological study of 100 cases. J Neurol Neurosurg Psychiatry. 1992;55 (3):181-4.

3. Papapetropoulos S, Mash DC. Psychotic symptoms in Parkinson's disease. From description to etiology. J Neurol. 2005;252(7):753-64.

4. Lee AH, Weintraub D. Psychosis in Parkinson's disease without dementia: common and comorbid with other non-motor symptoms. Mov Disord. 2012;27(7):858-63

5. Amerikan Psikiyatri Birliği. Mental Bozuklukların Tanısal ve Sayımsal El Kitabı, Beşinci baskı (DSM5) (Çev. ed. E. Köroğlu) Hekimler Aankara. Yayın Birliği, 2013.

6. Akbostancı MC, Balaban H, Atbaşoğlu C. Birleşik Parkinson Hastalığı Değerlendirme Ölçeği motor muayene bölümü ve anormal istemsiz hareketler ölçeğinin değerlendiriciler arası güvenilirlik çalışması. Parkinson Hastalığı ve Hareket Bozuklukları Dergisi. 2000;3:7-13.

7. Hoehn MM, Yahr MD. Parkinsonism: onset, progression and mortality. Neurology. 1967;17(5):427-42.

8. Folstein MF, Folstein SE, McHugh PR. Minimental state. A practical method for grading the cognitive state of patients fort the cilinican. J Physchiatr Res. 1975;12(3):189-98.

9. Gungen C, Ertan T, Eker E, Yaşar R, Engin F. Reliability and validity of the standardized minimental state examination in the diagnosis of mild dementia in Turkish population. Turk Psikiyatri Derg. 2002;13(4):273-81 
10. Ramaker C, Marinus J, Stiggelbout AM, Van Hilten BJ. Systematic evaluation of rating scales for impairment and disability in Parkinson's disease. Mov Disord. 2002;17(5):867-76.

11. Levin J, Hasan A, Höglinger GU. Psychosis in Parkinson's disease: identification, prevention and treatment. J Neural Transm (Vienna). 2016;123(1):45-50.

12. Onofrj M, Espay AJ, Bonanni L, Delli Pizzi S, Sensi SL. Hallucinations, somatic-functional disorders of PD-DLB as expressions of thalamic dysfunction. Mov Disord. 2019;34(8):1100-11.

13. Williams DR, Lees AJ. Visual hallucinations in the diagnosis of idiopathic Parkinson's disease: a retrospective autopsy study. Lancet Neurol. 2005;4(10):605-10.

14. Factor SA, Molho ES, Podskalny GD, Brown D. Parkinson's disease: drug-induced psychiatric states. Adv Neurol. 1995;65:115-38.

15. Pagonabarraga J, Martinez-Horta S, Fernández de Bobadilla R, Pérez J, Ribosa-Nogué R, Marín J et al. Minor hallucinations occur in drug-naive Parkinson's disease patients, even from the premotor phase. Mov Disord. 2016;31(1):45-52.

16. Kulisevsky J, Roldan E. Hallucinations and sleep disturbances in Parkinson's disease. Neurology. 2004;63(3):28-30.

17. Panchal SC, Ondo WG. Treating hallucinations and delusions associated with Parkinson's disease psychosis. Curr Psychiatry Rep. 2018;20(1):3.

18. Fenelon, G. Alves G. Epidemiology of psychosis in Parkinson's disease, J. Neurol. Sci.2010;289(12):12-7.

19. Wu DD, Li SH, Jin LY, Jin Y, Cui YY, Zhao H et al. Influencing factors of visual hallucinations in patients with Parkinson's disease and its relationship with sleep disorders. Zhonghua Yi Xue Za Zhi. 2016;96(13):1016-20.
20. Fenelon G, Soulas T, Cleret de Langavant L, Trinkler I, Bachoud-Levi AC. Feeling of presence in Parkinson's disease. J Neurol Neurosurg Psychiatry 2011;82(11):1219-1224.

21. Fenelon G, Soulas T, Zenashi F, Langavant FC. The changing face of Parkinson's disease associated psychosis: a cross-sectional study based on the new NINDS-NIMH criteria. Mov Disord. 2010;25(6):763-6.

22. Williams DR, Warren JD, Lees AJ. Using the presence of visual hallucinations to differentiate Parkinson's disease from atypical parkinsonism. J Neurol Neurosurg. Psychiatry. 2008;79(6):652-5.

23. Inzelberg R, Kippervasser S, Korczn AD. Auditory hallucinations in Parkinson's disease. J Neurol Neurosurg Psychiatry. 1998;64(4):533-5.

24. Fenelon G, Mahieux F, Huon R, Ziegler M. Hallucinations in Parkinson's disease. Prevalence, phenomenology and risk factors. Brain. 2000;123(4):733-45.

25. Marsh L, Williams JR, Rocco M, Grill S, Munro C, Dawson TM. Psychiatric comorbidities in patients with Parkinson disease and psychosis. Neurology. 2004;63(2):293-300.

26. Holroyd S, Currie L, Wooten G.F. Prospective study of hallucinations and delusions in Parkinson's disease, J. Neurol. Neurosurg. Psychiatry. 2001;70(6):734-8. 